\title{
Abortion and a Right to Health in International Law: L.C. v Peru
}

\author{
Charlotte Bates*
}

\section{Keywords}

Abortion, international law, Latin America, reproductive rights, CEDAW, Peru

\section{Introduction}

In November 2011, the Committee on the Elimination of Discrimination Against Women decided a complaint originating from Peru. The complaint concerned a young woman, L.C., who was denied access to a safe and legal abortion that she required so that she could undergo urgent medical treatment. This article will address the decision, its place in international human rights law, and its likely impact, if any, on abortion legislation in Peru.

\section{The facts}

Between 2006 and 2007, when L.C. was 13-14 years old, she was repeatedly raped by a 34 -year-old man over period of several months. ${ }^{1}$ She became pregnant, but told no one. Desperate and depressed, she attempted suicide by throwing herself off the roof of the building next to her home, ${ }^{2}$ fracturing several vertebrae and leaving her quadriplegic. A senior surgeon concluded that her spine needed to be realigned immediately ${ }^{3}$ to increase the chances of future mobility. ${ }^{4}$ The surgery was scheduled for 12 April $2007 .^{5}$

\footnotetext{
LLM, University of Birmingham. I would like to thank Professor Sonia Harris-Short for reading parts of this article as part of my Masters thesis, and for encouraging me to pursue this research.

1 Center for Reproductive Rights, 'L.C. v. Peru (UN Committee on the Elimination of Discrimination against Women)' <http://reproductiverights.org/en/case/lc-v-peru-un-committee-on-theelimination-of-discrimination-against-women> [accessed 25 July 2013].

2 Ibid.

${ }^{3}$ Ibid.

${ }^{4}$ Human Rights Watch, My Rights, and My Right to Know: Lack of Access to Therapeutic Abortion in Peru (2008), paras 15-16.

${ }^{5}$ LC v Peru, C/50/D/22/2009 (4 November 2011) (CEDAW), para 2.1.
}

Copyright $\odot$ the Author(s).

This work is licensed under a Creative Commons Attribution-NonCommercial-NoDerivs 3.0 License. 
When L.C. was examined prior to her surgery, her sexual abuse and pregnancy were revealed. ${ }^{6}$ At this point L.C. was around 8 weeks pregnant. ${ }^{7}$ Doctors would not operate while she was pregnant, even though the medical staff recognised that her physical mobility was continuing to deteriorate between 2 and 12 April. ${ }^{8}$ She was also given no psychiatric treatment for her depression, as this was contraindicated during pregnancy. ${ }^{9}$

L.C.'s mother requested a therapeutic abortion for her daughter in accordance with Article 119 of the Penal Code, to allow L.C. to have the operation. ${ }^{10}$ Article 119 provides that abortion is not punishable when it is the only means to save the life of the woman or to avoid serious and permanent damage to her health.'11

After several meetings and unexplained delays, the hospital medical committee refused the petition on the grounds that the pregnancy no longer posed a threat to L.C.'s physical health. ${ }^{12}$ In contrast, a medical report relied on by L.C.'s legal team from the High-Level Commission on Reproductive Health of the Medical College of Peru concluded that ' $[t]$ here are sufficient reasons to state that, if the pregnancy continues, there is grave risk to the girl's physical and mental health; a therapeutic abortion, if requested by the subject, would therefore be justified. ${ }^{13}$

On 11 July 2007, L.C. miscarried in hospital due to the severity of her injuries. Doctors finally performed the spinal surgery, three and a half months after it was deemed necessary. ${ }^{14}$ By that time any operation would have had little or no effect on restoring her physical capacity. ${ }^{15}$ Furthermore, after her discharge from hospital on 31 July, the intensive course of physiotherapy recommended in the hospital reports did not begin until 10 December. ${ }^{16}$ "[T]he months of delay cost [L.C.] control of her body. She cannot walk at all, has no control of her bowels, and can barely use her arms and hands. ${ }^{, 17}$ Her condition prevents her from attending school, and the expense of her treatment has meant that her brothers have had to

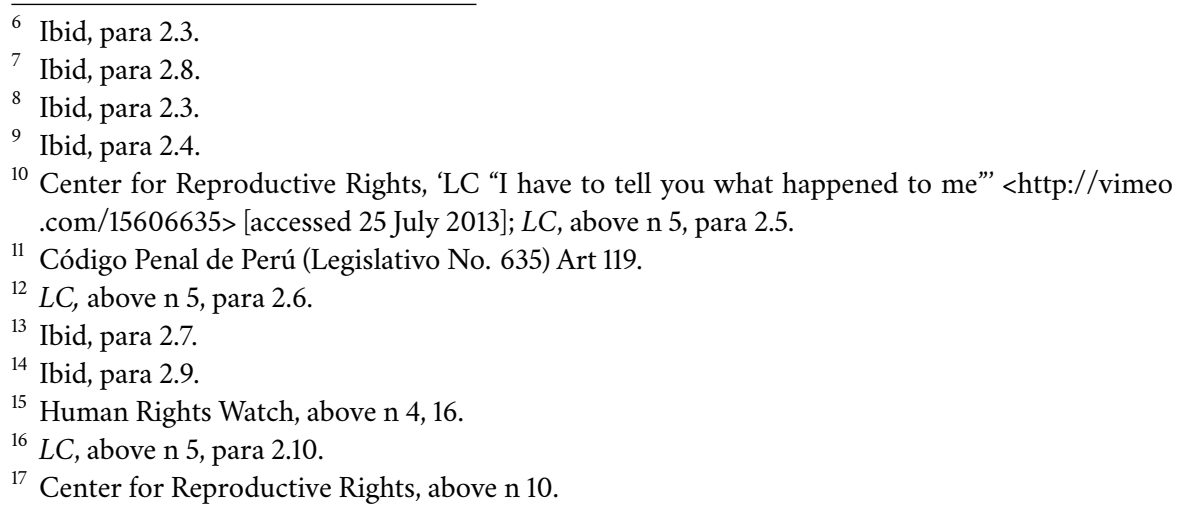


leave school and begin working. ${ }^{18}$

\section{National law background}

Abortion is a second category offence in Peru's 1991 Penal Code. Article 114 provides that a woman who causes her abortion or consents to another performing one upon her will be sentenced to up to 2 years' imprisonment or between 52 and 104 days of community service. ${ }^{19}$ For the provider of a consensual abortion, Article 115 provides a sentence of between one and four years' imprisonment. If the woman dies and this is a foreseeable result, the term increases to between two and five years. ${ }^{20}$ Article 117 states that if the provider is a 'doctor, obstetrician, pharmaceutical, or any health professional', the sentence is aggravated, and the provider is disqualified from practice. ${ }^{21}$ Article 30 of the Peruvian General Health Law (26842) also requires healthcare providers to report to the police women who are suspected of inducing an unauthorised abortion. ${ }^{22}$ The sentence is mitigated to up to three months' imprisonment where there has been a rape or where the foetus has 'serious physical or psychological defects', under Article 120 of the Penal Code. ${ }^{23}$ An abortion in these circumstances is still a criminal offence.

The only exception to the general criminalisation of abortion is Article 119 . It provides that abortion is not punishable when it is the only means to save the life of the woman or to avoid serious and permanent damage to her health. ${ }^{24}$ However, neither the constitutional provisions on abortion, nor the current General Health law, provide for any regulations on the procedure for accessing an abortion: the decision lies at the discretion of the patient's doctors. ${ }^{25}$ There is no judicial mechanism for challenging the doctors' decision. ${ }^{26}$

In contrast, Article 2 of the Peruvian Constitution of 1993 provides that '[e]very person has the right to life, his identity, his moral, psychic and physical integrity and his free development and well-being. The unborn child is a

\footnotetext{
${ }^{18}$ LC, above n 5, para 2.11.

${ }^{19}$ Código Penal de Perú, Art 114.

${ }^{20}$ Ibid, Art 115.

${ }^{21}$ Ibid, Art 117.

${ }^{22}$ Human Rights Watch, above n 4, 20.

${ }^{23}$ Código Penal de Perú, Art 120.

${ }^{24}$ Ibid, Art 119.

${ }^{25} L C$, above $\mathrm{n} 5$, para 2.13 .

${ }^{26}$ Ibid, para 5.7.
} 
rights-bearing subject, in any event which is beneficial for him. ${ }^{, 27}$ In recent cases involving the use of emergency contraception, the Peruvian Constitutional Court has made clear that it will prioritise the interests of the unborn over those of the woman. $^{28}$ The Court found that a zygote (fertilized ovum) has a right to life. Although the emergency contraceptive pill is not an abortifacient, the court found that it should be treated as causing an abortion because it prevents the zygote from implanting in the uterus wall, and thus violates the unborn's right to life. ${ }^{29}$

These legal provisions give very little guidance to doctors, hospital management or lawyers about when an abortion is not criminal, or how to approach reconciling Article 119 of the Penal Code and Article 2 of the Constitution. It is suggested here that there is also doubt whether the legal effect of Article 119 is to create a right to an abortion to save the life or permanent health of the mother, in the sense of placing a duty on another to provide one. ${ }^{30}$ The provision is framed as an immunity-an absence of liability-from punishment for abortion: ${ }^{31}$ no clear duty is imposed on the state that a woman could rely on as conferring a positive right to an abortion. In contrast, the Constitution explicitly gives rights to the unborn, and there is a constitutional duty on officials to protect such rights.

\section{The right to health and non-discrimination in access to health services}

L.C.'s legal team alleged that the refusal of the hospital to allow her to access a legal therapeutic abortion violated her rights 'to health, a life of dignity and to be free from discrimination in access to such care. ${ }^{32}$ The most important Convention rights for these purposes are Articles 12 and 2 of the Convention on the Elimination of Discrimination Against Women (CEDAW).

The health and reproductive rights in CEDAW are, in practical terms, very important for giving effect to women's health rights. Peru is not a signatory to

\footnotetext{
${ }^{27}$ Constitución Política del Perú (ratified 31st October 1993, enacted 29 December 1993), Art 2 (emphasis added).

${ }^{28} \mathrm{M}$ Cardenas, 'Banning emergency contraception in Latin America: Constitutional Courts granting an absolute right to life to the zygote' (2009) 6 Houmboult American Comparative Law Review 359.

${ }^{29}$ Ibid.

${ }^{30}$ W Hohfeld, 'Fundamental Legal Conceptions as Applied in Judicial Reasoning' (1917) Yale Law Journal $710,723$.

${ }^{31}$ Ibid, 738.

${ }^{32}$ L.C., above n 5, para 3.8 .
} 
the Optional Protocol to the International Covenant on Economic, Social and Cultural Rights (CESCR), which means that although Peru is bound by CESCR, if women take their complaints to United Nations bodies then they must rely on rights in other Conventions which they can bring to an international hearing. The purpose of CEDAW is to eliminate gender discrimination in women's exercise of all human rights, including economic, social and cultural rights. ${ }^{33}$ This therefore includes the right to health in Article 12 of CESCR.

The right to health was recognised as a human right from the outset of modern international human rights law: the Universal Declaration on Human Rights. Article 25 provides not only that everyone has 'the right to a standard of living adequate for the health and well-being of himself and his family, including [...] medical care,', ${ }^{44}$ but also that 'Motherhood and childhood are entitled to special care and assistance. ${ }^{, 35}$ '[T] he right of everyone to the enjoyment of the highest attainable standard of physical and mental health ${ }^{36}$ was immortalised in treaty law in Article 12 of CESCR. The inclusion of both physical and mental health in Article 12 is significant, as it extends the remit of maternal health targets to the mental as well as the physical health of women. Indeed, in many countries, including Peru's neighbour, Colombia, mental health grounds are explicit exceptions to a general criminalisation of abortion. The Committee of Economic, Social and Cultural Rights' General Comment 14 further clarifies that this includes 'the right to control one's health and body, including sexual and reproductive freedom. ${ }^{37}$ This clearly indicates that issues involving fertility and pregnancy are encompassed by the right to health.

General Comment 14 provides the framework for the analysis of the right to health. It provides that four 'interrelated and essential elements ${ }^{38}$ make up the right to health: the availability, accessibility, acceptability and quality of health services. The L.C. case is clearly a matter of the accessibility of a medical procedure which is legally-but not physically-available to L.C.

The justiciability of Covenant rights is limited by Article 2 of CESCR: the

\footnotetext{
${ }^{33}$ Convention on the Elimination of All Forms of Discrimination Against Women, 18 December 1979, 1249 UNTS 13, Art 1.

${ }^{34}$ Universal Declaration of Human Rights, GA res 217A (III), UN Doc A/810, 10 December 1948, Art 25.

${ }^{35}$ Ibid, Art 25(2).

${ }^{36}$ International Covenant on Economic, Social and Cultural Rights, 16 December 1966, 993 UNTS 3, Art 12.

${ }^{37}$ Committee for Economic, Social and Cultural Rights, 'General Comment 14', UN Doc E/C.12/2000/4, 11 August 2000, para 8.

${ }^{38}$ Ibid, para 12.
} 
state only undertakes to guarantee the right 'to the maximum of its available resources, with a view to achieving progressively the full realisation of the rights recognized in the present Covenant.' ${ }^{39}$ However, Article 2 imposes an obligation 'to take steps [which] should be deliberate, concrete and targeted as clearly as possible towards meeting the obligations recognized in the Covenant. ${ }^{\text {,40 }}$ The state cannot therefore abstain from responsibility entirely: it is under an obligation to take action according to its means. The right to health is also protected regionally by the Additional Protocol to the American Convention on Human Rights in the Area of Economic, Social and Cultural Rights. ${ }^{41}$

The Committee on the Rights of the Child went further in elaborating the meaning of 'maximum available resources'. It has suggested that 'resources must be understood as encompassing not only financial resources but also other types of resources relevant for the realisation of economic, social and cultural rights such as human, technological, organisation, natural and information resources.' $^{\text {.42 }}$ This statement is likely to apply to the application of this article across committees. Thus, while the state has a margin of appreciation as to the allocation of financial resources, a lack of funding will not in itself act as an excuse. The organisation of those resources and organisation of professionals to provide care is also relevant. This could include, for example, ensuring the availability of doctors who do not conscientiously object to abortion to make decisions on whether the necessary legal conditions for an abortion exist.

The South African Constitutional Court has been instrumental in proving the justiciability of economic, social and cultural rights to the rest of the world. An important case for our purposes is Ministry of Health $v$ Treatment Action Campaign, ${ }^{43}$ which concerned the implementation of a treatment plan for pregnant women and new mothers with HIV. The government argued that nevirapine, a drug shown to be effective at preventing the transmission of HIV during birth, had not been made widely available because more research was needed into the efficacy of a care package containing a range of measures designed to also prevent post-natal mother-to-child infection on their nominated

\footnotetext{
${ }^{39}$ CESCR, Art 12.

${ }^{40}$ Committee for Economic, Social and Cultural Rights, 'General Comment 3', UN Doc E/1991/23, 14 December 1990, para 2.

${ }^{41}$ Additional Protocol to the American Convention on Human Rights in the Area of Economic, Social and Cultural Rights, 17 November 1988, Art 10.

${ }^{42}$ Committee on the Rights of the Child, Report on the Forty-Sixth Session, UN Doc CRC/C/46/3, 22 April 2008, ch VII, para 65.

${ }^{43}$ Ministry of Health $v$ Treatment Action Campaign [2002] ZACC 15
} 
test sites. The court held that while this was important, it 'was not a reason for not allowing the administration of the nevirapine' in other parts of the public health system. This demonstration of justiciability at national level is important because the Optional Protocol to CESCR, which allows individuals from states party to it to bring complaints to an international body, was only recently approved, ${ }^{44}$ and many states, including Peru, are not parties to it.

Article 2 of CESCR also provides that Covenant rights should 'be exercised without discrimination of any kind' including on grounds of sex and language. ${ }^{45}$ Non-discrimination in healthcare on grounds of sex has been further bolstered by the Committee on Economic, Social and Cultural Rights' General Comment 16 and Article 12 of CEDAW. These provide for the equal enjoyment of Convention rights between men and women, ${ }^{46}$ including in 'family planning, ${ }^{47}$ and 'appropriate services in connection with pregnancy, confinement and the post-natal period. ${ }^{48}$ These provisions clarify that discrimination can occur not only when there is a difference in treatment between men and women, but also indirectly when services used only by women, including maternal and reproductive healthcare, are neglected.

Internationally, reproductive choice has been successfully asserted as a negative right. In the case of María Mamerita Mestanza Chávez v Peru, Peru accepted responsibility for not guaranteeing the rights of a woman who was harassed into undergoing sterilisation without her informed consent. ${ }^{49}$ However, where reproductive choice has been asserted as a positive right, success has been more limited, as this requires the state to delegate a duty to physicians and to expend resources. ${ }^{50}$ However, it is suggested here that, given that states, including Peru, have committed to improving funding for family planning in Millennium Development Goal $5,^{51}$ this is becoming an increasingly weak

\footnotetext{
${ }_{44}$ Optional Protocol to the International Covenant on Economic, Social and Cultural Rights, GA Res 63/117, 10 December 2008.

${ }^{45}$ CESCR, Art 12.

${ }^{46}$ Committee for Economic, Social and Cultural Rights, 'General Comment 16', UN Doc E/C.12/2005/4, 11 August 2005, para 29.

${ }^{47}$ CEDAW, Art 12(1).

${ }^{48}$ Ibid, Art 12(2).

${ }^{49}$ María Mamerita Mestanza Chávez v Peru, Case 12.191, Resolution N 71/03 (10 October 2003) (Friendly settlement).

${ }^{50}$ R Cook, B Dickens \& M Fathalla, Reproductive Health and Human Rights: integrating medicine, ethics and law (2003), 52.

${ }^{51}$ United Nations, 'Millennium Development Goals', (United Nations Millennium Summit, New York, 2000), Goal 5 Target B.
} 
justification. The International Conference on Population and Development Programme for Action strongly emphasises that the fulfilment of reproductive health rights is a state obligation. ${ }^{52}$

While the Committee on the Elimination of Discrimination Against Women had previously recognised that the prevalence of unsafe abortion in the region is a 'major cause of maternal mortality' and that the criminalisation of abortion 'may lead women to seek unsafe, illegal abortions, with consequent risks to their life and health', ${ }^{53}$ it has historically seemed reluctant to endorse safe and legal abortion as a solution, even in soft law. The International Women's Health Conference for Cairo '94, held in Rio de Janeiro nine months before the International Conference on Population and Development Programme for Action in Cairo, created an opportunity for Cairo to endorse abortion access. It recommended that " $\mathrm{t}$ ] $\mathrm{he} \mathrm{UN}$ and other donors and governments should recognize the right to a safe and legal abortion as an intrinsic part of women's rights and governments should change legislation and implement policies to better reflect such a recognition. ${ }^{54}$ However, the Cairo Programme for Action did not adopt this stance: the compromise between states that supported and opposed abortion resulted in statements that government policy should be about preventing abortion, ${ }^{55}$ and that 'all attempts should be made to eliminate the need for abortion.' ${ }^{56}$ This view is also represented in the Committee on the Elimination of Discrimination Against Women's General Recommendation 19, which states that there is a positive obligation on states 'to ensure that women are not forced to seek unsafe medical procedures such as illegal abortion because of lack of appropriate services in regard to fertility control. ${ }^{57}$

${ }^{52}$ United Nations, Report of the International Conference on Population and Development, UN Doc A/CONF.171/13, 18 October 1994, Chapter 7.

${ }^{53}$ E.g. Committee on the Elimination of Discrimination Against Women, 'Concluding comments of the Committee on the Elimination of Discrimination against Women: Chile', UN Doc CEDAW/C/CHI/CO/4, 26 August 2006, para 19; Human Rights Committee, 'Concluding Observations of the Human Rights Committee: Chile', UN Doc CCPR/C/79/Add.104, 3 March 1999, para 13; Committee on the Elimination of Discrimination Against Women, 'Concluding comments of the Committee on the Elimination of Discrimination against Women: Mexico', UN Doc A/53/38/Rev. 1, 6 February 1998, para 426.

${ }^{54}$ S Corrêa, Population and reproductive rights: feminist perspectives from the South (1994) 65-6 (emphasis added).

${ }^{55}$ United Nations, above n 52, paras 7.6, 7.24.

${ }^{56}$ Ibid, para 8.25 .

${ }^{57}$ Committee on the Elimination of All Forms of Discrimination Against Women, 'General Recommendation 19: Violence against Women', UN Doc A/47/38, 11 Session 1992, para 24(m) (emphasis added). 


\section{Other rights of the woman in international law}

CEDAW also provided for some additional rights that L.C. relied upon. These include specific rights to 'information and advice on family planning ${ }^{\text {,5 }}$ and the right to decide the number and spacing of children. ${ }^{59}$ The former United Nations Special Rapporteur for Violence Against Women has stated that '[d]irect State action violative of women's reproductive rights can be found [...] in criminal sanctions against [...] abortion. ${ }^{\prime 60}$

Furthermore, it was argued in L.C. that the violations, including lack of administrative action and the failure to provide an administrative remedy to protect women from discrimination, ${ }^{61}$ were aggrevated as they did not give special attention required by her status as a minor. ${ }^{62}$ An argument was also made that the irreparable consequences for her life and health [...] constituted suffering equivalent to torture. 63

The procedural arguments in the L.C. case are particularly important in the Peruvian context, because of a previous decision against Peru from the Human Rights Committee. K.L. v Peru ${ }^{64}$ concerned a 17 -year-old girl carrying an anencephalic foetus. Anencephaly is a defect that leaves foetal skull bones unformed and is both untreatable and certain to cause the infant's death during or shortly after birth. ${ }^{65}$ It can also endanger the mother's life. ${ }^{66}$ In K.L., the hospital obstetrician advised a termination, but the availability of an abortion was subject to the approval of the hospital director. ${ }^{67}$ The director refused to authorise an abortion, stating that under Article 120 of the Penal Code, abortions of deformed foetuses were criminal. ${ }^{68}$ The refusal of an abortion served to 'prolong the distress and emotional instability' of K.L., who suffered from severe depression as a result of continuing with the pregnancy. ${ }^{69}$ After the birth, she further 'endure[d]

\footnotetext{
${ }^{58}$ CEDAW, Art 10(1)h.

${ }^{59}$ Ibid, Art 16(1)e.

${ }^{60}$ United Nations High Commission on Refugees, Report of the Special Rapporteur on Violence against Women, its causes and consequences, UN Doc E/CN.4/1999/68/Add.4, 21 January 1999, para 44.

${ }^{61}$ L.C., above n 5 , para 3.2 .

${ }^{62}$ Ibid, para 3.5-6.

${ }^{63}$ Ibid, para 3.4.

${ }^{64}$ K.L. v Peru, CCPR/C/85/D/1153/2003 (3 November 2005) (HRC).

${ }^{65}$ B Dickens, 'Prenatal management of anencephaly' (2008) 102 International Journal of Gynecology and Obstetrics 304, 304.

${ }^{66}$ K.L., above n 64, para 2.7

${ }^{67}$ Ibid, paras 2.2-3.

${ }^{68}$ Ibid, para 2.3.

${ }^{69}$ Ibid, para 2.5 .
} 
the distress of seeing her daughter's marked deformities ${ }^{70}$ by being forced to breastfeed for four days until the baby died. ${ }^{71}$ The Human Rights Committee found that the 'refusal of the competent medical authorities to provide the service may have endangered the [mother's] life [and] that no effective remedy was available to her to oppose that decision. ${ }^{72}$ This amounted to a violation of the girl's rights to life (Article 6), privacy and family life (Article 17) and freedom from cruel, inhuman or degrading treatment (Article 7) under the Covenant on Civil and Political Rights. The Committee also found a violation of the positive obligation of the state to protect minors (Article 24) ${ }^{73}$ 'since she did not receive the special care she needed from the health authorities, as an adolescent girl. ${ }^{14}$ This is significant because the Human Rights Committee's General Comment 17 suggests that this obligation applies in relation to guaranteeing economic social and cultural, as well as civil and political, rights, ${ }^{75}$ and thus applies to the right to health of minors.

The Article 24 issue-the duty to protect minors-deserves some discussion, as it also applies to the L.C. case. It creates a difficulty for states, as they are no longer balancing the rights of an adult with an unborn child, but of a child-to whom they owe special duties of care-with an unborn child. Tobin has argued that in such a situation, it is not for the state to say simply that the child is exercising adult activities, and thus allow this special duty to be neglected. Rather, he says that 'the right to health, when used in conjunction with several other articles under the CRC [...] demands that appropriate measures be taken by states to minimize the risks to children's health which arise in the exercise of their sexual autonomy' ${ }^{76}$ If this is indeed true in relation to voluntary sexual activities, then surely it must be the case in relation to protecting children from the consequences of involuntary sexual activity.

This leads us to the issue of rape, a matter not outlined in the K.L. decision but relevant in the L.C. case. The Committee bodies have in general recommended that abortion should be allowed where the pregnancy is the result of rape or in-

\footnotetext{
${ }^{70}$ Ibid, para 6.3 .

${ }^{71}$ Ibid, paras 2.6, 6.3.

${ }^{72}$ Ibid, para 6.2.

${ }^{73}$ International Covenant on Civil and Political Rights, 16 December 1966, 999 UNTS 171, Arts 6, $7,17,24$.

${ }^{74}$ K.L., above n 64, para 37.

${ }^{75}$ Human Rights Committee, 'General Comment 17', UN Doc HRI/GEN/1/Rev.6, 7 April 1989, para 2-3.

${ }^{76} \mathrm{~J}$ Tobin, The Right to Health in International Law (2011) 134.
} 
cest, including in their recommendations to Peru. ${ }^{77}$ These are recommendations and thus fall within the margin of appreciation of the state, but their volume and the universality of this view held across the committees indicates a degree of consensus that this is a human rights conformity issue.

\section{Rights of the foetus in international law}

The Preamble of the Convention of the Rights of the Child 1989 states that 'the child, by reason of his physical and mental immaturity, needs special safeguards and care, including appropriate legal protection, before as well as after birth. ${ }^{, 78}$ This provision has generated considerable debate in Latin America.

Van Bueran argues that if childhood begins from the moment of conception $^{, 79}$ then the child has a right to life, ${ }^{80}$ which in practice would mean that 'abortion would be prohibited under international law' ${ }^{81}$ and that 'other rights, such as privacy and health, ${ }^{82}$ would be equally applicable to a foetus.

However, it is notable that the Convention itself does not clearly provide that any rights should be attributed to the unborn child: Article 1, which defines who is a child, omits to provide for any starting point from which a duty to protect Convention rights is imposed. In an earlier draft, a right to life from conception did exist in Article 1, but was removed as a compromise with states wanting to permit abortion. ${ }^{83}$ The Committee on the Rights of the Child has stated that the Preamble does not mean that countries that allow abortion should doubt their commitment to the Convention. It has publicly linked unsafe abortion and maternal mortality, ${ }^{84}$ and expressed concern about the impact of punitive legislation on maternal mortality rates. ${ }^{85}$ This suggests that Article 1 does not create foetal rights. However, several Central and South American

\footnotetext{
${ }_{77}$ E.g. Committee on Economic, Social and Cultural Rights, UN Doc E/C.12/PER/CO/2-4, para 21; Human Rights Council, UN Doc A/HRC/22/15, para 119.8 .

${ }^{78}$ Convention on the Rights of the Child, 20 November 1989, 1577 UNTS 3, Preamble (CRC) (emphasis added).

${ }^{79} \mathrm{G}$ Van Bueren, The International Law on the Rights of the Child (1995), 33.

${ }^{80}$ CRC, Art 6(1).

${ }^{81}$ Van Bueren, above n 79, 33.

${ }^{82}$ Ibid.

${ }^{83} \mathrm{Ibid}, 34$

${ }^{84}$ Committee on the Rights of the Child, 'General Comment 4: Adolescent Health', UN Doc CRC/GC/2003/4, 1 July 2003, para 31 .

${ }^{85}$ Committee on the Rights of the Child, 'Concluding Observations on Guatemala', UN Doc CRC/C/15/Add.154, 9 July 2001, para 40.
} 
states, including Argentina and Guatemala, have made declarations on ratifying or signing the Convention that they will protect a child from conception. ${ }^{86}$ Although Peru has not entered a declaration, its Constitution, as discussed earlier, would prima facie suggest that the government may share this belief. ${ }^{87}$

On a regional level, the American Convention on Human Rights, to which Peru is a party, protects life 'in general, from the moment of conception'. ${ }^{88}$ The legal position of the foetus under this Convention was clarified in the Baby Boy Case. ${ }^{89}$ In that case, the Inter-American Commission on Human Rights found that:

The addition of the phrase in general, from the moment of conception' does not mean that the drafters of the Convention intended to modify the concept of the right to life that prevailed in [the American Declaration of Human Rights]. The legal implications of the clause 'in general, from the moment of conception' are substantially different from the shorter clause 'from the moment of conception. 90

It therefore appears incorrect to read Article 4(1) as meaning that a positive right to life exists from the moment of conception, or as implicating this interpretation of national constitutions.

\section{The decision of the Committee on the Elimination of Discrimination Against Women}

In the L.C. case, the Committee on the Elimination of Discrimination Against Women found squarely in favour of L.C. It held that:

L.C. was a victim of exclusions and restrictions in access to health services based on a gender stereotype that understands the exercise of a woman's reproductive capacity as a duty rather than a right. By failing to comply with the legal duty to provide health services to L.C. (including reproductive health services), and having done so for discriminatory reasons arising from her status as a woman,

\footnotetext{
${ }^{86}$ Van Bueren, above n 79, para 34.

${ }^{87}$ Constitución Política del Perú, Art 2.

${ }^{88}$ American Convention on Human Rights, 12 November 1969, Art 4(1).

89 'Baby Boy', Case 2141, Res 23/81 (6 March 1981) (Merits).

${ }^{90}$ Ibid, para 30.
} 
considering her reproductive capacity of greater importance than her human rights, the State party violated articles 1 and 12 of the Convention. $^{91}$

In addition, '[t]he mental health of L.C. was completely overlooked in the evaluation concerning whether a therapeutic abortion was warranted'. ${ }^{92}$

The Committee also found that the state had failed to observe its General Recommendation 24 obligation to ensure the provision of certain reproductive health services and to establish a system that guarantees judicial remedies when it fails to do so. ${ }^{93}$ The absence of such a system 'created the conditions allowing agents of the state to discriminate against L.C. and prevented her access to the medical treatment she required, which also constitutes a violation of articles 1 and $12^{94}$ and Article 16(1)(e). ${ }^{95}$ The resultant failure to effectively protect the rights of women through national institutions violated Article 2.

In arguably its most important finding, the Committee considered that 'since the State party had legalised therapeutic abortion, it must establish an appropriate legal framework that allows women to exercise their right to it under conditions that guarantee the necessary legal security, both for those who have recourse to abortion and for the health professionals that must perform it. ${ }^{96}$ In particular, this framework should specify 'a mechanism for rapid decision-making', room for the woman's opinion to be taken into account, and a right to appeal. ${ }^{97}$

\section{Impact}

We have seen that the Peruvian system, which leaves decisions on balancing the legal rights of the woman-including a woman who is herself a minor-and unborn child in the hands of doctors operating under the risk of prosecution, requires the legislature to make difficult ethical decisions about which aims it considers to be legitimate. The L.C. case is clearly a victory for those in Peru who have for a long time advocated legal clarification of the procedure for obtaining a therapeutic abortion. Such a determination has been long-anticipated. After the K.L.

\footnotetext{
${ }^{91}$ L.C., above n 5 , para 7.7.

92 Ibid, para 7.6.

${ }^{93}$ Ibid, para 7.11 .

${ }^{94}$ Ibid, para 7.12 .

95 Ibid, para 7.14 .

${ }^{96}$ Ibid, para 8.17.

${ }^{97}$ Ibid.
} 
decision, in mid-2006 the Ministry of Health Working Group on Sexual and Reproductive Health was asked to develop a National Protocol ${ }^{98}$ that would implement the decision. In 2007, a public meeting to discuss the Protocol was cancelled and never rescheduled. ${ }^{99}$ Progress then stalled. In an attempt to establish internal guidance to doctors under the existing laws, the National Materno-Perinatal Institute issued a hospital-wide directive for the 'integral management of therapeutic abortion for gestations of less than 22 weeks', a copy of which was sent to the government. ${ }^{100}$ However, the Ministry of Health declared this directive null and void for exceeding administrative authority. ${ }^{101}$ Three hospital-level protocols at different institutions remain, but the implementation of rules to control discretion has not been supported by the Ministry of Health. ${ }^{102}$ Peru was again reminded of the need to implement national regulation of therapeutic abortion by the ESCR Committee in May 2012. ${ }^{103}$ The response given on this matter by Peru in its Universal Periodic Review in November 2012, was that the Protocol prepared by the National Materno-Perinatal Institute still existed and could be used for reference. ${ }^{104}$ However, the Human Rights Council did not think this was adequate and reaffirmed recommendations to "[a]dopt and implement a national protocol to guarantee equal access to therapeutic abortion for women and girls as part of sexual and reproductive health services'; ${ }^{\prime 05}$ '[a]dopt the necessary measures to inform women and girls about their rights related to access to sexual and reproductive health services, including the possibility of abortion, as established by domestic legislation'; ${ }^{106}$ and ' $[\mathrm{r}]$ eview its restrictive interpretation of therapeutic abortion and decriminalisation of abortion in cases of rape, as recommended by CEDAW'.107

The L.C. decision has clearly reaffirmed the need for Peru to resume discussions. To do so is not only part of the state's duty under the K.L. Decision;

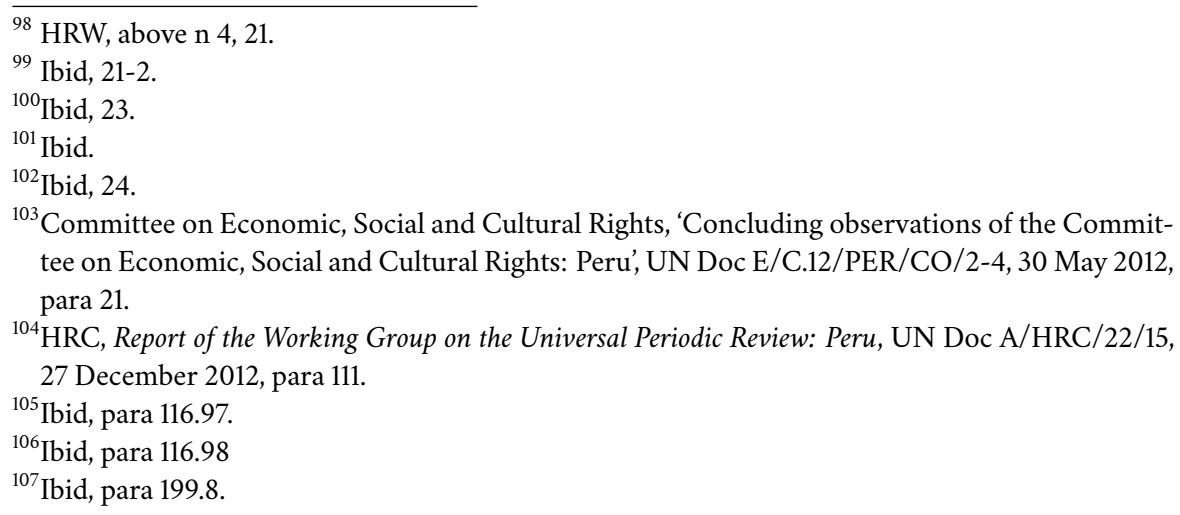


the ESCR Committee has stated that part of the state's duty to ensure a 'minimum core obligation' is to adopt a public health strategy and plan of action and to review those plans periodically including against indicators. ${ }^{108}$

As we have seen, international law 'accommodates the reality of the need for states to prioritize the allocation of scarce resources provided that the state is able to demonstrate that the process for allocating these resources can be shown to be reasonable. ${ }^{\prime 109}$ The issue here, however, is clearly not a financial one: indeed, an abortion was a far cheaper option than the ongoing care that L.C. will now require for the rest of her life. Rather, the issue is one of a lack of political will to allocate resources towards such a controversial procedure. However, where an abortion is lawfully available, but physicians fail to provide access-due to their own objection or a fear of prosecution-it will amount to a violation of the right to health by the state. The Cairo Plan of Action recommended that in circumstances where abortion is not against the law, health systems should train and equip health-service providers and should take other measures to ensure that such abortion is safe and accessible.. ${ }^{\prime 10}$ It is this resource-training-that is woefully inadequate in Peru.

The World Health Organisation has recommended a two-pronged approach for dealing with therapeutic abortion in countries such as Peru. The first is that states 'promote and review their relevant laws amongst physicians [...] and the general public, design and implement policies to ensure effective access to abortion to the extent that the law allows and remove unnecessary regulative and administrative barriers to access. ${ }^{111}$ In the Peruvian context, this would cover both the education of the profession, and the removal of the risk of prosecution for doctors who do misinterpret the law. The second recommendation is that states operate a mandatory referral scheme, where doctors who conscientiously object to the procedure refer women to another doctor who is willing to perform abortions. ${ }^{112}$ This suggestion gives rise to a number of issues. It keeps the decision-making power on a legal as well as a medical matter in the hands of doctors, which means that specialist training for those who are willing to carry

\footnotetext{
${ }^{108}$ Committee on Economic, Social and Cultural Rights, 'General Comment No 3: The Nature of States Parties' Obligations', UN Doc E/1991/23,14 December 1990, annex III, para 10.

${ }^{109}$ Tobin, above n 76, 12 .

${ }^{110}$ United Nations, Key Actions for the Further Implementation of the Programme of Action of the International Conference on Population and Development, GA Res S21/2, UN Doc A/RES/S-21/2, 8 November 1999, para 63(iii).

${ }^{111}$ Tobin, above n 76, 164.

${ }^{112}$ Ibid, 164-5.
} 
out the procedure is required. It also relies on the integrity of doctors to state truthfully their objection or lack of it, both of which could leave the individual open to criticism. A mandatory referral system may thus interfere with the right to freedom of religion and belief of some doctors. While the legitimate aim of the health of women and girls is satisfied, ${ }^{113}$ it does not remove the need to protect doctors.

The decision, however, also highlights the importance of considering the views of the woman and her rights to appeal, which make the education of individuals about their rights prominent in the process too. It leaves questions: whose responsibility is this? Is it the doctor's? Surely not: doctors making a legal decision because it is based on medical grounds is a difficulty in itself, without also making them responsible for educating others about the law. This gives rise to a further resource issue: how are lawyers to become involved in this decision and representation process on behalf of the woman, and who will bear the costs? There is also an issue of capacity where the woman is herself a child, as was the case in L.C..

That this path is the one that will eventually be followed is less certain. The L.C. decision clearly grounded its arguments in the fact that Article 119 of the Penal Code exempts from criminalisation abortions carried out for therapeutic reasons. The CEDAW Committee would like to see is a set of guidelines to ensure that this exemption operates in a manner closer to a right to therapeutic abortion. Yet there is another possible outcome. The decision does not suggest that the rights to health or to decide the number and spacing of one's children in the Convention create a right to a therapeutic abortion. This therefore means that complete prohibitions on abortion remain compatible with international law. It thus, hypothetically at least, remains open to Peru to follow Nicaragua in reverting back to an absolute prohibition on abortion, a move that would have a negative impact on the rights and freedoms of Peruvian women. The hesitance to suggest that international human rights law has created conditions where access to a therapeutic abortion must be procedurally available when the woman's health would be significantly compromised, or denial would have an effect amounting to torture, means that there is still no recourse available for women in countries with an absolute prohibition on abortion. The issue is so controversial that international decision-making bodies have given deference to national decision-makers on the issue of legal availability.

How long this deference can last, given these international rulings, is

${ }^{113}$ Ibid, 165. 
somewhat questionable. The L.C. case indicates that it is not only the failures in procedural accessibility that lead to violations of the complainants' rights; physical consequences to their health and life may do so as well. Unfortunately, the current legal rulings create no incentive for religiously conservative states to liberalise their abortion law and procedural guidelines. This would be contrary to the spirit of these decisions. 